\title{
The Use Of Liquid Smoke As Latex Coagulant For Rubber Farmer Group In Bukit Liti Village, Central Kalimantan
}

\section{Pemanfaatan Asap Cair Sebagal Bahan Penggumpal lateks Bagi Kelompok Petani Karet Di Desa Bukit Liti, Kalimantan Tengah}

\author{
Lilis Rosmainar $^{(1)}$ Karelius $^{(1)}$ Rasidah $^{(1)}$ I Nyoman Sudyana ${ }^{(1)}$ Nyahu Rumbang ${ }^{(2)}$ Idam Sulastri ${ }^{(1)}$ \\ 1), Program Studi Kimia FMIPA, Universitas Palangka Raya \\ 2), Program Studi Pendidikan Kimia FKIP, Universitas Palangka Raya \\ e-mail:karelius@chem.upr.ac.id
}

\begin{abstract}
Bukit Liti Village is one of villages located in the Kahayan Tengah Sub-district, Pulang Pisau Regency, Central Kalimantan Province. Most people there tap rubber tree simply managed to produce bokar (rubber materials). In making bokar, rubber farmers use coagulant materials that can damage the rubber quality and soak bokar in water pool/creeks which lower the rubber quality and produce bad smell. To solve the problem, a training is conducted to make a simple pyrolysis reactor to produce liquid smoke which will be used as latex coagulant preventing and reducing bad smell and improving the bokar quality. Pyrolysis reactor is made from a used oil tank, and other materials with a thermometer to measure reactor temperature. The reactor is designed to allow a minimum oxygen combustion. The production of rubber wood liquid smoke for latex coagulation process in this research with $50 \mathrm{~kg}$ of old rubber wood materials has obtained $125 \mathrm{ml}$ liquid smoke for 4-hour production time. The use of liquid smoke as latex coagulant gives real impacts for farmers such as: environmental friendly, to prevent bacterial growth and oxidation in the latex and latex lump, to prevent and reduce bad smells of bokar from the plantation, during storage and rubber processing in the rubber processing factory. The technology advantages of the liquid smoke are: faster coagulation, high elasticity, able to increase dry rubber content, relatively same price with other coagulant, to increase quality and selling price, produce clean latex and free of environment pollutant.
\end{abstract}

Keywords: latex, liquid smoke, bokar.

\section{ABSTRAK}

Desa Bukit Liti merupakan salah satu desa yang berada di wilayah Kecamatan Kahayan Tengah, Kabupaten Pulang Pisau, Provinsi Kalimantan Tengah. Kebanyakan masyarakat menyadap karet yang masih dikelola secara sederhana dan menghasilkan olahan karet yang disebut bokar. Petani-petani karet membuat bokar masih menggunakan bahan pembeku yang dapat merusak mutu karet dan merendam bokar di dalam kolam/sungai sehingga menyebabkan terjadi kerusakan pada mutu karet dan menimbulkan bau busuk. Dilakukan pelatihan pembuatan reaktor pirolisis sederhana untuk menghasilkan asap cair yang akan digunakan sebagai penggumpal lateks, mencegah dan mengurangi bau busuk dan memperbaiki kualitas bahan olahan karet. Reaktor pirolisis dibuat dengan menggunakan bahan dasar drum bekas, dan bahan lain serta dilengkapi dengan termometer sebagai pengukur suhu reaktor. Reaktor dirancang sedemikian rupa sehingga proses pembakaran yang terjadi didalam reaktor terjadi dengan kondisi minim oksigen. Produksi asap cair kayu karet untuk proses pembekuan lateks pada kegiatan ini dengan bahan dasar kayu karet tua sebanyak $50 \mathrm{~kg}$ menghasilkan produksi asap cair $125 \mathrm{ml}$ dengan waktu produksi asap cair selama 4 jam. Bahan olahan karet (bokar) yang dihasilkan berwarna coklat keemasan pada produk yang diakibatkan oleh reaksi pencoklatan non enzimatis oleh senyawa karbonil pada asap cairterhadap protein lateks dan karet. Hasil pengamatan dari aspek teknis, asap cair mampu sebagai koagulan dan pengawet koagulum lateks. Penggunaan asap cair sebagai pembeku lateks memberikan dampak nyata kepada petani diantaranya adalah: ramah lingkungan, mencegah pertumbuhan bakteri dan oksidasi didalam lateks dan gumpalan lateks, mencegah dan mengurangi bau busuk bahan olah karet sejak dari kebun, selama penyimpanan dan pengolahan karet di pabrik pengolahan karet. Sedangkan keunggulan teknologi dari penggunaan asap cair adalah: Pembekuan lebih cepat, elastisitas tinggi, dapat meningkatkan kadar karet kering (K3), harga relatif sama dengan pembeku lain, meningkatkan kualitas dan harga jual, lateks yang dihasilkan bersih dan tidak mencemari lingkungan.

Keywords: Lateks, Asap Cair, dan Bokar.

\section{PENDAHULUAN}

Desa Bukit Liti merupakan salah satu desa yang secara administratif berada di wilayah Kecamatan Kahayan Tengah, Kabupaten Pulang Pisau, Provinsi 
Kalimantan Tengah. Desa Bukit Liti mempunyai luas wilayah 9.461,10 $\mathrm{Ha}$ dengan tingkat kepadatan penduduk sudah mencapai 925 jiwa. Lokasinya berjarak $\pm 35 \mathrm{~km}$ dari ibukota Provinsi Kalimantan Tengah, Palangka Raya dan berjarak $\pm 130 \mathrm{~km}$ dari Kabupaten Pulang Pisau, serta $\pm 12 \mathrm{~km}$ dari ibu kota Kecamatan Kahayan Tengah.

Desa Bukit Liti terdiri dari 3 RT dengan masing-masing RT I berjumlah 105 KK, RT II berjumlah 76 KK dan RT III berjumlah 86 KK. Topografi Desa Bukit Liti terdiri dari perbukitan rata-rata $60 \%$ dan dataran rata-rata $40 \%$. Desa Bukit Liti masih belum berkembang dikarenakan dari total luas wilayah desa ini \pm 4.000 Ha masih berupa kawasan hutan belantara, sedangkan luas lahan perkebunan 250 Ha dan luas lahan pemukiman hanya \pm $50 \mathrm{Ha}$ (BPS 2016). Keseharian masyarakat Desa Bukit Liti adalah bercocok tanam, bertani, beternak, tambang masyarakat dan menyadap karet. Di sepanjang jalan pedesaan masyarakat sudah aktif menanam karet dan menyadap karet dengan cara tradisional.
Potensi yang paling menonjol dari Desa Bukit Liti adalah perkebunan karet. Sebagian besar penduduknya bermata pencaharian sebagai petani karet yang masih dikelola secara sederhana. Di Desa Bukit Liti ada 2 perusahaan yang menampung hasil kebun karet warga. Sebelum hasil olahan karet warga (bokar) dijual kepada perusahaan, para petani karet biasanya menyimpan terlebih dahulu karet yang mereka hasilkan, bila jumlah bokar sudah mencukupi, baru kemudian dijual ke perusahaan. Sampai saat ini, petani-petani karet di Desa Danau Bukit Liti membuat bokar masih menggunakan bahan pembeku yang dapat merusak mutu karet seperti cuka para TSP dan tawas. Disamping itu, petani juga merendam bokar di dalam kolam/sungai selama 7-14 hari. Hal ini dapat menyebabkan terjadi kerusakan pada mutu karet juga menimbulkan bau busuk yang sangat mengganggu masyarakat sekitar tempat petani mengolah lateks. Rendahnya mutu karet yang dihasilkan tentunya merugikan petani karet, karena harga jual karet menjadi rendah.

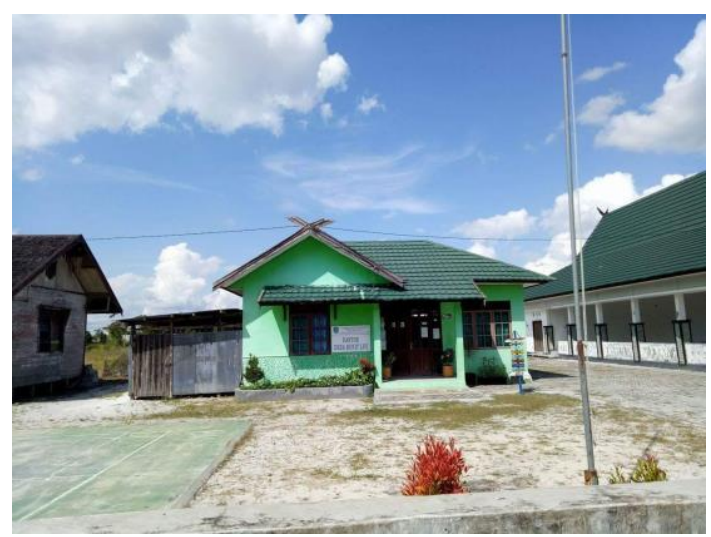

Gambar 1. Kantor Desa Bukit Liti

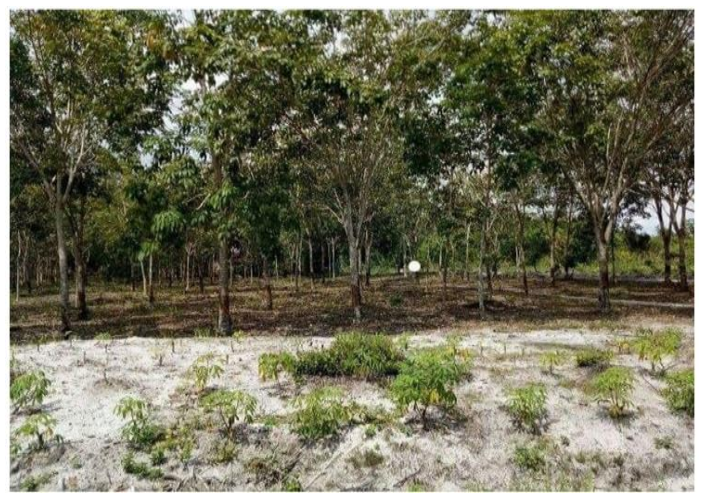

Gambar 2. Perkebunan Karet di Desa Bukit Liti

Berdasarkan hasil diskusi dengan perangkat desa dan perwakilan masyarakat Desa Bukit Liti, dirumuskan ada 2 (dua) permasalahan utama yang memerlukan bantuan penanganan, antara lain:

1 akses jalan menuju desa di beberapa ruas jalan belum teraspal ataupun belum dicor beton
2 pengawetan karet oleh para petani yang masih tradisional sehingga seringkali karet berbau menyebabkan harga jual karet rendah.

Dari kedua permasalahan di atas, ditentukan permasalahan yang akan bersama-sama dicari alternatif penyelesaiannya, yaitu permasalahan 2, 
untuk permasalahan 1 belum memungkinkan untuk diatasi oleh tim pengusul, mengingat keterbatasan dana dan waktu.

Sebagaimana diketahui, harga jual karet rendah karena rendahnya kualitas bokar yang dihasilkan. Bokar rusak karena petani karet masih menggunakan bahan pembeku yang dapat merusak mutu karet seperti cuka para TSP dan tawas, selain itu petani karet juga merendam olahan karet (bokar) di dalam kolam/sungai selama 7-14 hari. Hal ini dapat menyebabkan terjadi kerusakan pada mutu karet juga menimbulkan bau busuk yang sangat mengganggu masyarakat sekitar tempat petani mengolah lateks. Kebiasaan yang selama ini dilakukan akan memacu berkembangnya bakteri perusak antioksidan alami di dalam bokar, sehingga nilai plastisitas awal (Po) dan plastisitas setelah dipanaskan menjadi rendah.

\section{METODE PELAKSANAAN PENGABDIAN}

Dalam kegiatan yang berbentuk pendidikan dan pelatihan, masyarakat diposisikan sebagai peserta, sedangkan tutor dan narasumber diperankan oleh tim pelaksana PkM. Ada beberapa metode/model yang diterapkan dalam pelaksanaan PkM, antara lain:

1. Model Partisipatory Rural Apprasial (PRA)

Model PRA menekankan pada keterlibatan masyarakat, digunakan untuk mengidentifikasi masalah yang dialami mitra atau kelompok masyarakat. Mitra harus diikutsertakan dalam kegiatan merumuskan masalah, mengatasi masalah, penentuan proses dan kriteria masalah.

2. Model Technology Transfer (TT)

Model TT dimaksud adalah penguasaan prinsipprinsip penerapan teknologi terutama yang berkaitan dengan program yang akan dilaksanakan.

\section{Tahapan Pelaksanaan PkM}

Adapun alur/tahapan pelaksanaan PkM Desa Bukit Liti dapat dilihat Gambar di bawah ini:

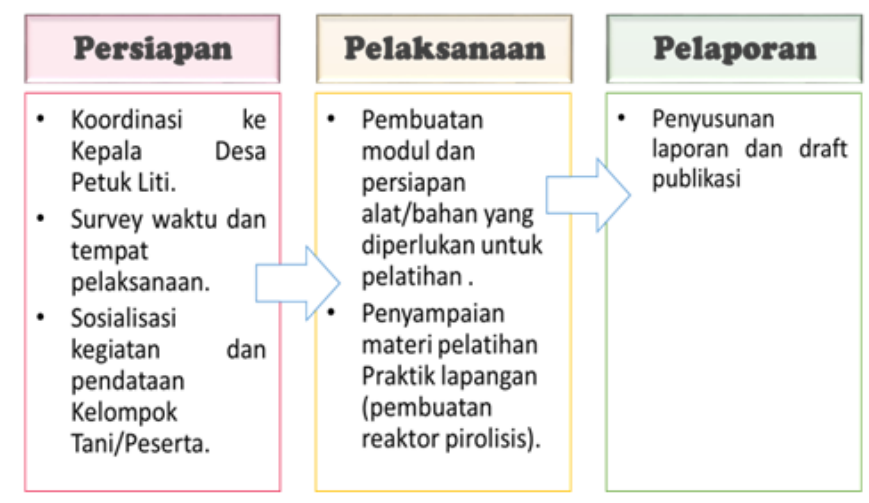

Gambar 3. Diagram alir pelaksanaan PkM Desa Bukit Liti

\section{Partisipasi Masyarakat}

Sebelum kegiatan pengabdian masyarakat, tim pengusul akan melakukan koordinasi dengan aparat Desa Bukit Liti dan beberapa perwakilan masyarakat, di mana solusi yang ditawarkan merupakan hasil kesepakatan bersama. Sehingga dalam pelaksanaannya nanti, diyakini masyarakat akan berpartisipasi aktif untuk membantu tim pelaksana. Peran masyarakat tersebut merupakan bukti kesadaran dan keinginan mereka untuk mendapatkan kehidupan yang lebih baik, terutama dalam pengawetan karet.

\section{Evaluasi Pelaksanaan Program}

Pada akhir program PkM, tim pelaksana akan melakukan evaluasi terhadap pelaksanaan dengan melakukan survei sederhana terhadap pendapat masyarakat terkait pelaksanaan program, serta harapan mereka terhadap kegiatan selanjutnya. Selain itu, tim pelaksana juga akan melakukan pengecekan terhadap instalasi terpasang beberapa bulan kemudian, untuk mengetahui nilai kemanfaatan yang dirasakan BALANGA: Jurnal Pendidikan Teknologi dan Kejuruan ISSN 2338-426X oleh masyaratakat dan juga pengecekan terhadap peralatan terpasang.

\section{HASIL DAN PEMBAHASAN}

Kegiatan PKM dilaksanakan mulai minggu ke4 di bulan April 2020, yaitu tahap persiapan. Dimulai dengan tahap penyusunan modul pelatihan, yang direncanakan akan selesai dalam waktu 1 minggu. Tahap persiapan awal sudah dilaksanakan, tim sudah melakukan koordinasi dengan kepala desa setempat mengenai kegiatan PKM, dan mereka menyambut baik kegiatan ini. Berdasarkan hasil koordinasi dengan kepala desa dan perwakilan warga, pelaksanaan kegiatan pelatihan direncanakan akan dilaksanakan pada minggu ke-2 bulan Mei sampai minggu ke-1 bulan Juni 2020.

Warga sangat antusias mengikuti pelatihan, ini terbukti dengan banyaknya pertanyaan yang diajukan oleh mereka selama 1 jam sesi tanya jawab. Bahkan beberapa warga mengusulkan agar bahan dan peralatan yang diberikan kepada desa Bukit Liti dapat 
segera dimanfaatkan untuk membuka industri rumah tangga, yang nantinya dapat dirasakan hasilnya oleh seluruh warga, walaupun pengelolaannya dilakukan oleh pihak aparat desa.

Secara umum, kegiatan PKM ini berlangsung dengan sukses, dan warga desa Bukit Liti berharap dapat dilaksanakan lagi pada tahun-tahun mendatang. Berikut ini adalah hasil dan pembahasan kegiatan PKM yang dilakukan di Desa Bukit Liti:

\section{Pelatihan Pembuatan Reaktor Pirolisis Sederhana}

Sebagian besar petani karet di Desa Bukit Liti membuat bahan olahan karet (bokar) masih menggunakan bahan pembeku yang dapat merusak mutu karet seperti cuka para TSP dan tawas. Disamping itu, petani juga merendam bokar di dalam kolam/sungai selama 7-14 hari. Hal ini dapat menyebabkan terjadi kerusakan pada mutu karet juga menimbulkan bau busuk yang sangat mengganggu masyarakat sekitar tempat petani mengolah lateks. Kebiasaan yang selama ini dilakukan akan memacu berkembangnya bakteri perusak antioksidan alami di dalam bokar, sehingga nilai plastisitas awal $\left(\mathrm{P}_{\mathrm{o}}\right)$ dan plastisitas setelah dipanaskan selama 30 menit pada suhu $140{ }^{\circ} \mathrm{C}$ (PRI) menjadi rendah.

Bau busuk disebabkan pertumbuhan bakteri pembusuk yang melakukan biodegradasi protein di dalam bokar menjadi amonia dan sulfida. Kedua hal tersebut terjadi karena bahan pembeku lateks yang digunakan saat ini tidak dapat mencegah pertumbuhan bakteri. Untuk mengatasi masalah tersebut, saat ini telah ditemukan asap cair bahan pembeku karet yang terbuat dari batang karet tua dan merupakan formulasi asap cair dan asam-asam organik yang mengandung senyawa fenol, yang dapat mencegah dan mematikan pertumbuhan bakteri, serta berfungsi sebagai antioksidan, dan berbau asap.

Reaktor pirolisis dibuat dengan menggunakan bahan dasar drum bekas, dan bahan lain serta dilengkapi dengan termometer sebagai pengukur suhu reaktor. Reaktor dirancang sedemikian rupa sehingga proses pembakaran yang terjadi didalam reaktor terjadi dengan kondisi minim oksigen. Asap yang dihasilkan kemudian dialirkan melalui pipa kondensor yang dialiri dengan air sungai sehingga asap mengalami kondensasi menjadi asap cair (liquid smoke). Reaktor pirolisis sederhana yang dirancang sebagai berikut:

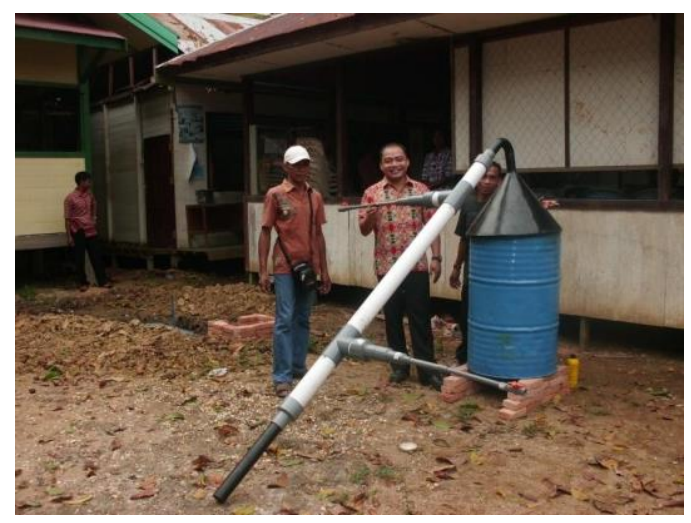

Gambar 4. Reaktor pirolisis sederhana

Pada pelatihan dan penyuluhan tentang perancangan reaktor pirolisis sederhana terhadap warga petani karet di Desa Bukit Liti, Kecamatan Kahayan Tengah, warga menyambut dengan baik terhadap kegiatan ini, seperti terlihat pada gambar berikut:

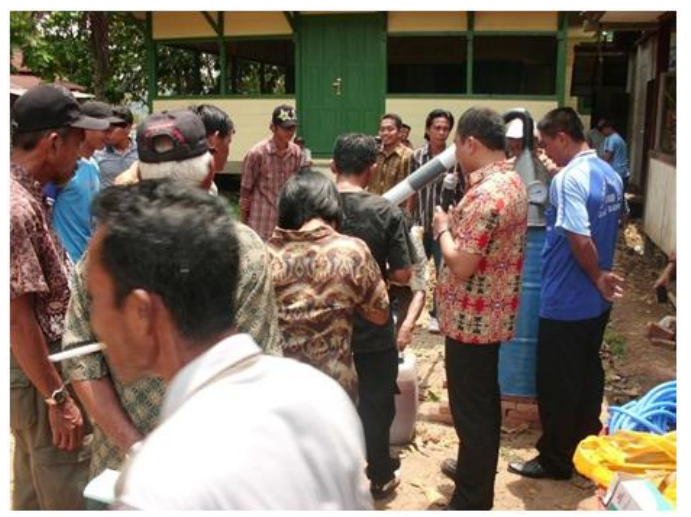

Gambar 5. Pelatihan perancangan reaktor pirolisis sederhana 
Menurut para petani karet masalah yang mereka hadapi selama ini adalah bahan olahan karet (bokar) yang mereka hasilkan bermasalah dalam hal bau serta kualitas karet yang rendah, sehingga harga jual karet ke tengkulak juga rendah. Kualitas karet yang rendah terutama karena petani karet lebih mengutamakan pada berat basah karet yang akan mereka jual, tanpa memperhatikan kualitasnya. Agar diperoleh berat yang optimal maka para petani karet biasanya merendam bokar dalam waktu yang relatif lama dalam sungai atau kolam sehingga kadar air karet menjadi tinggi dan merusak mutu karet. Melalui pelatihan ini, diharapkan para petani karet dapat memperbaiki kualitas bokar yang mereka hasilkan dengan mengaplikasikan asap cair sebagai penggumpal lateks dan penghilang bau yang efektif.

Produksi asap cair kayu karet untuk proses pembekuan lateks pada kegiatan ini dengan bahan dasar kayu karet tua sebanyak $50 \mathrm{~kg}$ dihasilkan produksi asap cair $125 \mathrm{ml}$ dengan waktu produksi asap cair selama 4 jam. Jika sebanyak $100 \mathrm{~kg}$ kayu karet tua yang dipirolisis untuk maka dalam satu hari mampu diproduksi sekitar $250 \mathrm{ml}$ asap cair.

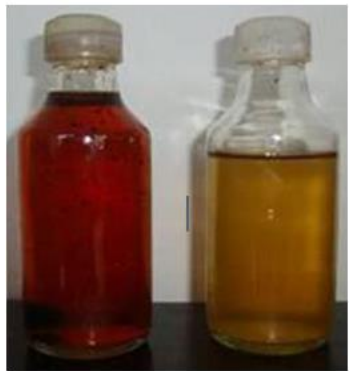

Gambar 6. Asap cair pekat (coklat tua) dan hasil pengenceran (kuning)

Pada aplikasi asap cair pada proses pembekuan lateks, larutan asap cair pekat diencerkan terlebih dahulu menjadi larutan asap cair 5\% dengan cara mencampurkan satu bagian larutan asap cair pekat dengan 19 bagian air bersih. Pemberian pada lateks dilakukan dengan cara mencampurkan satu bagian larutan asap cair 5\% dengan 10-12 bagian lateks. Sehingga dengan demikian 1 liter asap cair pekat dapat membekukan 200-250 liter lateks atau setara dengan 75 kg karet kering. Pemberian dilakukan segera dilakukan setelah mangkuk sadap penuh, dan masukan lateks dalam wadah dan tambahkan asap cair 5\%, kemudian diaduk dan biarkan beku menjadi slab. Hasil yang diperoleh disimpan di tempat kering dan bersih.

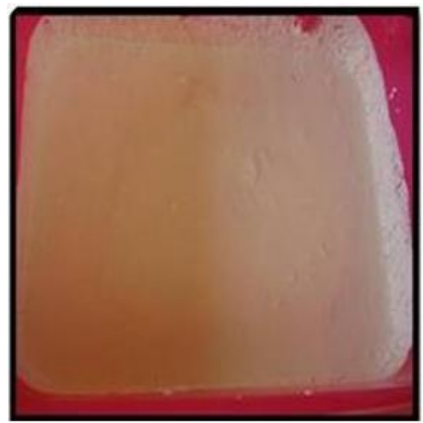

Gambar 7. Hasil aplikasi asap cair pada lateks cair

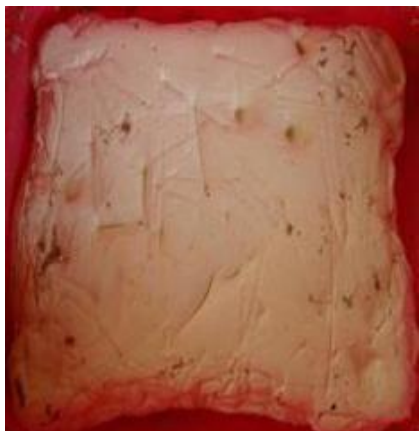

Gambar 8. Hasil aplikasi asap cair pada lateks beku 
Bahan olahan karet (bokar) yang dihasilkan berwarna coklat keemasan pada produk yang diakibatkan oleh reaksi pencoklatan non enzimatis oleh senyawa karbonil pada asap cairterhadap protein lateks dan karet (Darmadji, dkk.,1999). Perlakuan yang diberikan dengan menggunakan asap cair kayu karet tua sebagai koagulan dan pengawet lateks beku rakyat (bokar). Hasil pengamatan dari aspek teknis asap cair mampu sebagai koagulan dan pengawet koagulum lateks dilihat dari pengamatan sifat fisik koagulum lateks seperti warna, bau, tekstur permukaan, jamur dan lain sebagainya.

Penggunaan asap cair sebagai pembeku lateks memberikan dampak nyata kepada petani diantaranya adalah: ramah lingkungan, mencegah pertumbuhan bakteri dan oksidasi didalam lateks dan gumpalan lateks, mencegah dan mengurangi bau busuk bahan olah karet sejak dari kebun, selama penyimpanan dan pengolahan karet di pabrik pengolahan karet. Sedangkan keunggulan teknologi dari penggunaan asap cair adalah: Pembekuan lebih cepat, elastisitas tinggi, dapat meningkatkan kadar karet kering (K3), harga relatif sama dengan pembeku lain, meningkatkan kualitas dan harga jual, lateks yang dihasilkan bersih dan tidak mencemari lingkungan.

\section{KESIMPULAN}

a) Masyarakat di Desa Bukit Liti menyambut dengan baik kegiatan pengabdian kepada masyarakat yang dilaksanakan oleh Universitas Palangka Raya, ke depan mereka berharap dilakukan kegiatan PKM secara rutin di desa tersebut.

b) Produksi asap cair kayu karet untuk proses pembekuan lateks pada kegiatan ini dengan bahan dasar kayu karet tua sebanyak $50 \mathrm{~kg}$ dihasilkan produksi asap cair $125 \mathrm{~mL}$ dengan waktu produksi asap cair selama 4 jam.

c) Penggunaan asap cair sebagai pembeku lateks memberikan dampak nyata kepada petani yaitu ramah lingkungan, efektif sebagai penggumpal lateks, mencegah dan mengurangi bau busuk bahan olah karet dan memperbaiki kualitas bahan olahan karet.

\section{DAFTAR PUSTAKA}

Badan Pusat Statistik Kabupaten Pulang Pisau. 2015. Kecamatan Banama Tingang Dalam Angka 2015. Badan Pusat Statistik Kabupaten Pulang Pisau

Darmadji, P. 1995. Produksi asap cair dan sifat fungsionalnya [Laporan Penelitian]. Yogyakarta: Fakultas Teknologi Pertani-an, Universitas Gadjah Mada .

Suhardi, Darmadji, P., Supranto, Herminiwati dan Rofig R Zulhari, (1998). Optimasi pembuatan arang aktif dari limbah kayu kering sebagai filler barang karet. Prosiding Seminar Nasional PATPIp80

Tranggono, S., B. Setiadji, P. Darmadji, Supranto, dan Sudarmanto. 1997. Identiflkasi asap cair dari berbagai jenis kayu dan tempurung kelapa. Jurnal Ilmu dan Teknologi Pangan 1(2): 15-24. 